\title{
Influence of size grading on physiological parameters in Tephrosia (Tephrosia purpurea) MDU (KO)-1
}

\section{S. Sivasubramaniam*, S. Ambika and M. Vetrivel}

Department of Seed Science and Technology, Tamil Nadu Agricultural University, Coimbatore-641003 (TN), INDIA

*Corresponding author. E-mail: seedmani@yahoo.com

Received: June 12, 2016; Revised received: October 20, 2016; Accepted: February 27, 2017

Abstract: Seed grading is an important practice for better crop establishment and to improve efficiency of planting ratio in field and also useful in separation of quality seed in a seed lot. The influence of seed size on physiological and biochemical seed quality characters were evaluated in Tephrosia seeds using seeds retained on 5.5/64", 6/64" and 7/64" sieves along with control. The estimations revealed that larger size seeds retained on 7/64" sieves recorded the maximum recovery $(64 \%), 100$ seed weight $(2.0 \mathrm{~g})$, speed of germination (14.1) germination ( $86 \%)$, root length $(8.5 \mathrm{~cm})$, shoot length $(11.0 \mathrm{~cm})$, dry matter production $\left(15.92 \mathrm{mg}\right.$ seedlings $\left.{ }^{-10}\right)$, vigour index $(1677)$ and protein (10.56\%) compared to BSS 5.5 / 64", BSS 6 / 64" and ungraded seeds.

Keywords: Germination, Seed weight, Sieve, Size grading, Tephrosia

\section{INTRODUCTION}

Non availability of green manure quality seed is one of the major constraints in increasing the productivity of agricultural crops. Seed grading is an integral part of seed production for enhanced planting value. Studies pertaining to seed grading based on seed size in relation to seed quality characters are warranted as amount of food reserve in seed is the basic requirement for its future expression as germination, and final establishment at field. In addition to obtain uniform seed size within a variety, size grading is inevitable. Seed size is one of the components of seed quality which affects the performance of crop (Ojo, 2000; Adebisi, 2004 and Adebisi et al., 2011). Jute cv. JRO 524 AND JRO 8432 seeds size graded using BSS 16x 16 sieves recorded higher seed quality standards (Jerlin et al., 2010). Large seeds produced the highest germination per cent, coleoptiles fresh weight, coleoptiles dry weight, radicle fresh weight and 1000 seed weights compared to other seed size in safflower (Sadeghi et al., 2011). Therefore, studies were made in tephrosia to fix optimum sieve size to obtain the required seed quality characters for higher planting value.

\section{MATERIALS AND METHODS}

Genetically pure and freshly harvested tephrosia (Tephrosia purpurea) MDU (KO) - 1 seeds were formed the base material for the study. The precleaned Kolingi seeds were size graded using sieve sizes 5.5/64", 6/64" and 7/64" wire mesh sieves. To calculate the recovery percentage, seeds retained in each of the sieves were weighed and expressed as respective percentage of total quantity of seeds processed. The seeds retained in each sieve were subjected to the following quality estimation along the ungraded bulk (control).

Seed recovery: The weight of seeds obtained from each grades were weighed separately and seed recovery was worked out using the following formula and expressed in per cent.

Seed recovery $(\%)=$ Weight of graded seeds in each grade / Total weight of ungraded seed X 100

Hundred seed weight (g): Eight replications of one 100 seeds from each replication were chosen at random and their weight was recorded on electronic balance as per ISTA procedure (Anonymous, 1999) and average weight was expressed in $\mathrm{g}$.

Speed of germination: The seeds showing plumule emergence were counted daily from third day after sowing until seventh day. The number of seeds germinated on each day was counted and the speed of germination was calculated using the following formula and the results were expressed in number (Maguire, 1962).

Speed of germination $=\frac{X_{1}}{Y_{1}}+\frac{X_{2}-X_{1}}{Y_{2}}+\ldots \ldots \ldots . . .+\frac{X_{n}-X_{n-1}}{Y_{n}}$

$X_{1}$ - Number of seeds germinated at first count $X_{2}$ - Number of seeds germinated at second count $\mathrm{X}_{\mathrm{n}}$ - Number of seeds germinated on $\mathrm{n}^{\text {th }}$ day

$Y_{1}$ - Number of days from sowing to first count $\mathrm{Y}_{2}$ - Number of days from sowing to second count $\mathrm{Y}_{\mathrm{n}}$ - Number of days from sowing to $\mathrm{n}^{\text {th }}$ count

Germination (\%): Seeds were soaked in hot water for 
30 minutes to break the dormancy. Germination test was carried out in quadruplicate using 100 seeds each with 4 sub replicates of 25 seeds, were carried out in rolled paper towel method (ISTA, 1999) in germination room maintained at $25 \pm 1{ }^{\circ} \mathrm{C}$ and $\mathrm{RH} 96 \pm 2 \%$ with diffused light during the day. On tenth day of germination test, numbers of normal seedlings were counted and the average was expressed as per cent.

Root length (cm): Ten normal seedlings were selected randomly from the germination test and root length was measured from tip of primary root to base of hypocotyls and mean root length was expressed in $\mathrm{cm}$.

Shoot length (cm): Ten normal seedlings chosen for measurement of root length were used for measurement of shoot length. It was measured from tip of primary leaf to base of hypocotyls and mean shoot length was expressed in $\mathrm{cm}$.

Seedling dry matter production (mg/10 seedlings): Ten normal seedlings chosen earlier for measuring shoot and root lengths were used to determine seedling dry weight. The seedlings kept in paper cover and dried under shade for $24 \mathrm{~h}$ and hot air oven at $85 \pm 1{ }^{\circ} \mathrm{C}$ for 24 hours. And the average weight was expressed in milligram per ten seedlings.

Vigour index: Seedling vigour index was computed by adopting the following formula as suggested by Abdul-Baki and Baker (1973) and was expressed in whole number.

\section{Vigour index $=$ Germination $(\%) \times$ Total seedling length (cm)}

Protein content: Protein content was estimated by the colorimetric method as described by Alikhan and Young (1973). One hundred milligram of ground seed meal was taken in a $50 \mathrm{ml}$ polyethylene screw cap bottle and $25 \mathrm{ml}$ of $1 \mathrm{~N}$ sodium hydroxide was added. The mixture was shaken for 15 minutes in a wrist shaker to disperse the protein. Then $10 \mathrm{ml}$ of the suspension was poured into a graduated test tube and used as a blank to compensate for the difference in the amount of natural pigments extracted. To the remaining suspension in bottle, $0.25 \mathrm{ml}$ of 10 per cent copper sulphate solution was added and the bottle was reshaken for five minutes to develop $\mathrm{F}$ the colour complex. The sample solution was then poured in to a separate test tube and kept overnight along with its blank to allow the dispersed material to settle

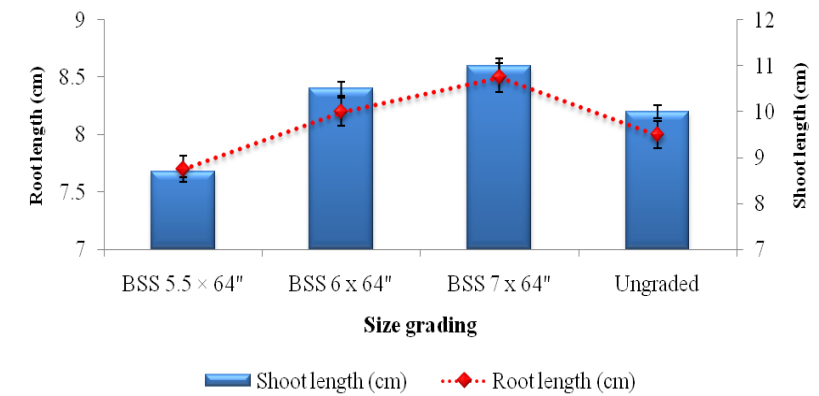

Fig. 1. Effect of size grading on shoot length $(\mathrm{cm})$ and root length (cm) in Tephrosia seeds.

down. The optical density of the clean supernatant solution obtained after centrifugation at $3000 \mathrm{rpm}$ for 10 minutes was measured in ELICO SL 150 spectrophotometer using a red filter $(620 \mathrm{~nm})$ against their respective blank. From the optical density values, the protein content was calculated using the following formula and the mean value of five replications was expressed in per cent.

Protein content $(\%)=3.78+(61.6 \times$ Optical density value)

\section{RESULTS AND DISCUSSION}

Seed recovery was significantly influenced by size grades. The seeds retained on BSS 7/64" sieves recorded the highest seed recovery of 64.0 per cent and the lowest was by the seeds passed through BSS 5.5 / 64" sieve $(10.2 \%)$. Size grades had significant influence on 100 seed weight. The seeds retained on BSS 7/64" sieve recorded the highest 100 seed weight $(2.0 \mathrm{~g})$ than those seeds passed through BSS 5.5/64", BSS 6/64" sieve and ungraded $(1.1,1.4$ and $1.5 \mathrm{~g}$, respectively) (Table 1). The 100 seed weight was also higher with the corresponding increase in seed size. Improved physical and physiological quality of graded seeds was reported in maize, which was revealed by higher germination percentage for large and medium sized seed (Silva and Marcos, 1979). Seeds retained in BSS 7/64" sieve were larger compared to other sieves. Hence, seeds retained by BSS 7/64" recorded higher speed of germination, germination $(\%)$, root length (cm) and shoot length (cm) $(14.1,86,8.5$ and 11.0, respectively) (Table 1 and Fig. 1) followed by the seeds retained by BSS 6/64". The higher germination

Table 1. Effect of size grading on seed recovery (\%), 100 seed weight (g), speed of germination, germination, dry matter production (mg seedling $\left.{ }^{-10}\right)$, vigour index and protein $(\%)$ in Tephrosia seeds.

\begin{tabular}{|c|c|c|c|c|c|c|c|}
\hline $\begin{array}{ll}\begin{array}{l}\text { Seed } \\
\text { grade }\end{array} & \text { size } \\
\end{array}$ & $\begin{array}{l}\text { Seed recov- } \\
\text { ery }(\%)\end{array}$ & $\begin{array}{l}100 \text { seed } \\
\text { weight }(g)\end{array}$ & $\begin{array}{l}\text { Speed of } \\
\text { germination }\end{array}$ & $\begin{array}{l}\text { Germina- } \\
\text { tion }(\%)\end{array}$ & $\begin{array}{l}\text { Dry matter produc- } \\
\text { tion (mg seedling-10) }\end{array}$ & $\begin{array}{l}\text { Vigour } \\
\text { index }\end{array}$ & $\begin{array}{l}\text { Protein } \\
\text { content }(\%)\end{array}$ \\
\hline BSS 5.5 / 64" & $10.20(18.63)$ & 1.126 & 10.3 & $56(62.03)$ & 11.98 & 918 & 9.73 \\
\hline BSS 6/64" & $25.80(30.53)$ & 1.460 & 14.1 & $82(64.90)$ & 14.25 & 1538 & 10.40 \\
\hline BSS 7/64" & $64.00(53.13)$ & 2.002 & 14.5 & $86(68.03)$ & 15.92 & 1677 & 10.56 \\
\hline Ungraded & & 1.590 & 13.7 & $78(62.03)$ & 13.72 & 1404 & 10.24 \\
\hline Mean & $33.33(35.24)$ & 1.544 & 13.2 & $76(60.67)$ & 13.97 & 1384 & 10.23 \\
\hline SE d & 0.987 & 0.059 & 0.227 & 1.248 & 0.569 & 44.236 & 0.146 \\
\hline $\mathrm{CD}(\mathrm{P}=0.05)$ & $2.414 * *$ & $0.109 * *$ & $0.524 * *$ & $2.877 * *$ & $1.235 * *$ & $102.073 * *$ & $0.317 * *$ \\
\hline
\end{tabular}

Figures in parentheses indicate arcsine values 
of larger seeds might be due to the higher amount of food reserves and increased activity of redox-enzyme in the seeds helping in faster breakdown of the complex food reserve materials into simple soluble sugars. The results are in conformity with the findings of Ndor et al. (2012) in pumpkin and Ahirwar (2012) in Alangium lamarckii Thwaites.

The other seed quality parameters like dry matter production (15.92 mg seedlings ${ }^{-10}$ ) and vigour index (1677) also endorsed the superiority of large size seeds retained by BSS 7/64" and BSS 6/64" sieves (Table 1). The relative high vigour associated with large sized seeds could be ascribed to well matured embryo and adequate nutrient reserves, which contributed towards its physiological stamina and vigour factor residing in it (Pollock and Roos, 1972). In addition to the greater quantity of storage materials and food reserves available in larger seeds, the seedling fresh weight, seedling mitochondrial protein, mitochondrial and biochemical activity, respiration rate and energy (ATP) production were also reported to be positively than the smaller seeds. Similar findings were also reported by Farahani et al. (2011) in wheat and Ponmani (2015) in barnyard millet. The vigour index of large and medium sized seeds were significantly superior to small seeds. This may be due to differences in their seed weight, germination potential, seedling length and stored food reserves (Styer et al., 1980). The protein content increased with increase in seed size and weight. The biochemical parameter like protein content $(10.56 \%)$ was maximum with larger size seeds which were retained in BSS 7/64", indicating the higher metabolic activity for germination of seeds.

\section{Conclusion}

Considering the higher recovery of seeds (64\%), germination (86\%), vigour parameters (1677) and protein content, Tephrosia MDU (KO)-1 seeds can be size graded using 7/64" sieve for getting good quality with higher planting value.

\section{REFERENCES}

Abdul-Baki, A. A. and Baker, J. E. (1973). Changes in cellular organelles for membranes related to vigour loss in seed. Seed Sci. \& Technol., 1: 89-125

Adebisi, M. A., Kehinde, T. O., Ajala, M. O., Olowu, E. F. and Rasaki, S. (2011). Assessment of seed quality and potential longevity in elite tropical soybean (Glycine
Max L.) Merrill grown in Southwestern Nigeria. Niger. Agric. J., 42: 94-103

Adebisi, M. A. (2004). Variaation stability and correlation studies in seed quality and yield components of sesame (Sesamum indicum L.). Ph. D. Thesis, University of Agriculture, Abeokuta, Nigeria

Ahirwar, J. R. (2012). Effect of seed size and weight on seed germination of Alangium lamarckii, Akola, India. Res. J. Recent Sci., 1:320-322

Ali-khan, S.T. and Youngs, C.G. (1973). Variation in protein content of field peas. Can. J. Pl. Sci., 53: 37-41.

Anonymous. (1999). International Rules for Seed Testing. International Seed Testing Association. Seed Sci. \& Technol., 4: 3-177

Farahani, H. A., Moaveni, P. and Maroufi, K. (2011). Effect of seed size on seedling production in wheat (Triticum aestivum L.). Adv. In Env. Bio., 5(7): 1711-1715

ISTA, (1999). International Rules for Seed Testing. Seed Sci. \& Technol., Supplement Rules, 27: 25-30

Jerlin, R., Menaka, C., Raja, K. Moorthy, K.R. and Tamilkumar, P. (2010). Standardization of sieve size for grading of olitorius jute seeds. Asian J. Agric. Res., 4: 15-19.

Maguire, J. D. (1962). Speed of germination - Aid in selection and evaluation of seedling emergence and vigour. Crop Sci., 2: 176-177

Ndor, E., Dauda, N.S. and Chammang, H.B. (2012). Effect of ermination media and seed size on germination and seedling vigour of fluted pumpkin (Telferia occidentalis) Hook. F. Adv. Environ. Biol., 2:113-115

Ojo, D. K. (2000). Studies on soybean seed quality and longevity improvement in the humid tropics. Ph. D. Thesis, University of Agriculture, Abeokuta, Nigeria

Pollock, B.M. and Roos, E.E. (1972). Seed and seedling vigour. In: Seed Biology - I (Ed. T.T. Kozlowski), Academic press New York Pp. 313-387

Ponmani, T. (2015). Studies on foliar nutrients, seed development and maturation and post harvest seed handling of barnyard millet (Echinochloa frumentacea L.). M.Sc., (Ag.) Thesis, Tamil Nadu Agricultural University, Coimbatore.

Sadeghi, H., Khazaei, F., Sheidaei, S. and Yari, L. (2011). Effect of seed size on seed germination behaviour of safflower (Carthamus tinctorius L.). J. Agric. Biol. Sci., 6: 5-8

Silva, W.R.D.A. and Marcos, F.J. (1979). Effect of weight and size of maize seeds on germination and vigour in the laboratory. Revista Brasileira de Sementes, $1: 34-52$

Styer, R. C., Cantliffe, D. J. and Hannah, L.C. (1980). Differential seed and seedling vigour in shrunken -2 compared to three other genotypes of corn at various stages of development. J. of American Soc. for Hort. Sci., 105: 329-331 